\title{
The tragic tale of a successful cure
}

\author{
Andrew Hague* \\ Professor of Advanced Medicine, President, Cellsonic, Manufacturers of Medical Equipment, United Kingdom
}

As you will see as the story unfolds, there must be anonymity for all concerned. Should you need further information and can assure me of your interest being only to successfully cure gangrene then I can tell you a lot more.

The case was first reported to me as follows:

\section{Case history}

Patient is 80 years old, female and diabetic, also suffering with Lucoderma.

Patient underwent bypass heart surgery on $2^{\text {nd }}$ November 2015 at ... Hospital. After the bypass surgery, the patient who was walking around suddenly observed setting of dry gangrene on the left foot, the condition of which deteriorated very fast.

The patient was shifted to ... Hospital by Dr. .... for the Cellsonic VIPP treatment.

As the patient is suffering from acute dry gangrene on the left foot, the doctors at ... Hospital concluded that the only recourse of treatment is amputation.

Dr. ... with the consent of the family has taken it as a challenge to salvage the foot to the maximum extent and thereby avoid amputation with the use of Cellsonic VIPP machine.

At that stage, the ability to cure gangrene with CellSonic VIPP (very intense pressure pulses) was only theoretical. The doctor, the patient and the patient's family were all against amputation. So I agreed to the treatment proceeding.

\section{Medical Definition of Gangrene (from medicine.net)}

Gangrene: Tissue death due to loss of adequate blood supply. Sometimes bacteria invade such tissue and accelerate its decay. Dry gangrene is the death of tissue due to vascular insufficiency without bacterial invasion in which the tissue dies, loses sensation and simply dries up, blackens, and shrivels. Dry gangrene eventually requires amputation.

To cure the gangrene CellSonic would have to cause increased vascularisation, kill any infection and restore failed nerves. Well documented results on wound healing in Germany confirmed that this is all possible.

\section{Report from the CellSonic team:}

- The fifth session therapy was to be administered on $1^{\text {st }}$ February 2016 but on $24^{\text {th }}$ January Cellsonic was informed that the patient had developed acute chest infection and was immediately shifted to the hospital's Intensive Care Unit (ICU).

- It was also decided to temporarily stop the Cellsonic VIPP treatment till the patient completely recovers from the chest ailment.
- The patient was discharged from the hospital on $16^{\text {th }}$ February 2016 and now is at home.

- The family has also consulted Dr. ... of .... Hospital for stem cell transplant but the doctor, looking at the progress made with the Cellsonic VIPP treatment, has strongly recommended to continue with the VIPP treatment.

- The next session is scheduled on $21^{\text {st }}$ February 2016 at the patient's residence in .....

In March 2016 I was in the city on business, visited the patient and observed a treatment. What was very clear was how happy she was despite being in her room all day. If I showed you her photo, it would contravene the anonymity that we must preserve. The important finding was that any poison in the gangrene that may have travelled up the leg to kill the patient had been stopped by the CellSonic pulses. She was not taking drugs and the dressings were only light bandages which were wrapped too tightly in my opinion but the nurse insisted she had to obey the doctor.

Here are the notes I wrote on $24^{\text {th }}$ June 2016:

I gave the decision to use CellSonic on Mrs ... and Dr ... agreed. He was amazed to see red under the black immediately the shocks hit the leg; blood was flowing. This immediate increase in blood flow has also been reported from Tubingen University where they used an instrument to measure the flow.

In March I was in ... and visited Mr and Mrs ... to confirm that by then there was no infection in her legs or feet. I watched a treatment. It started at energy level 4 (the range is from 1 to 10) and on the foot she was not showing signs of feeling anything. I ordered an increase of the energy level and it got to 10 when she said she could feel it. Ordinarily you would scream with pain. Then we worked under the foot and she could feel more. Eventually her big toes came to life and this told us that the nerves were working. Only the two smallest toes were unresponsive, and I expect them to fall off eventually.

The black, leathery skin is indeed dead. Under it is now healthy flesh with active nerves and blood flowing. The black leather is protecting the flesh and bones. At some stage the decision was made to cut away some of the dead skin because it was curling in and cutting into the foot. That left an open wound which is managed with dressings. New skin is growing, and a wound of this size could take a year for complete coverage.

Correspondence to: Andrew Hague, Professor of Advanced Medicine, President, Cellsonic, Manufacturers of Medical Equipment, UK, Tel: +1 315210 6307; E-mail: cellsonic.beauty@gmail.com

Received: November 13, 2017; Accepted: December 15, 2017; Published: December 19, 2017 


\section{Photographs of affected area ( left foot) before Cellsonic VIPP treatment :}
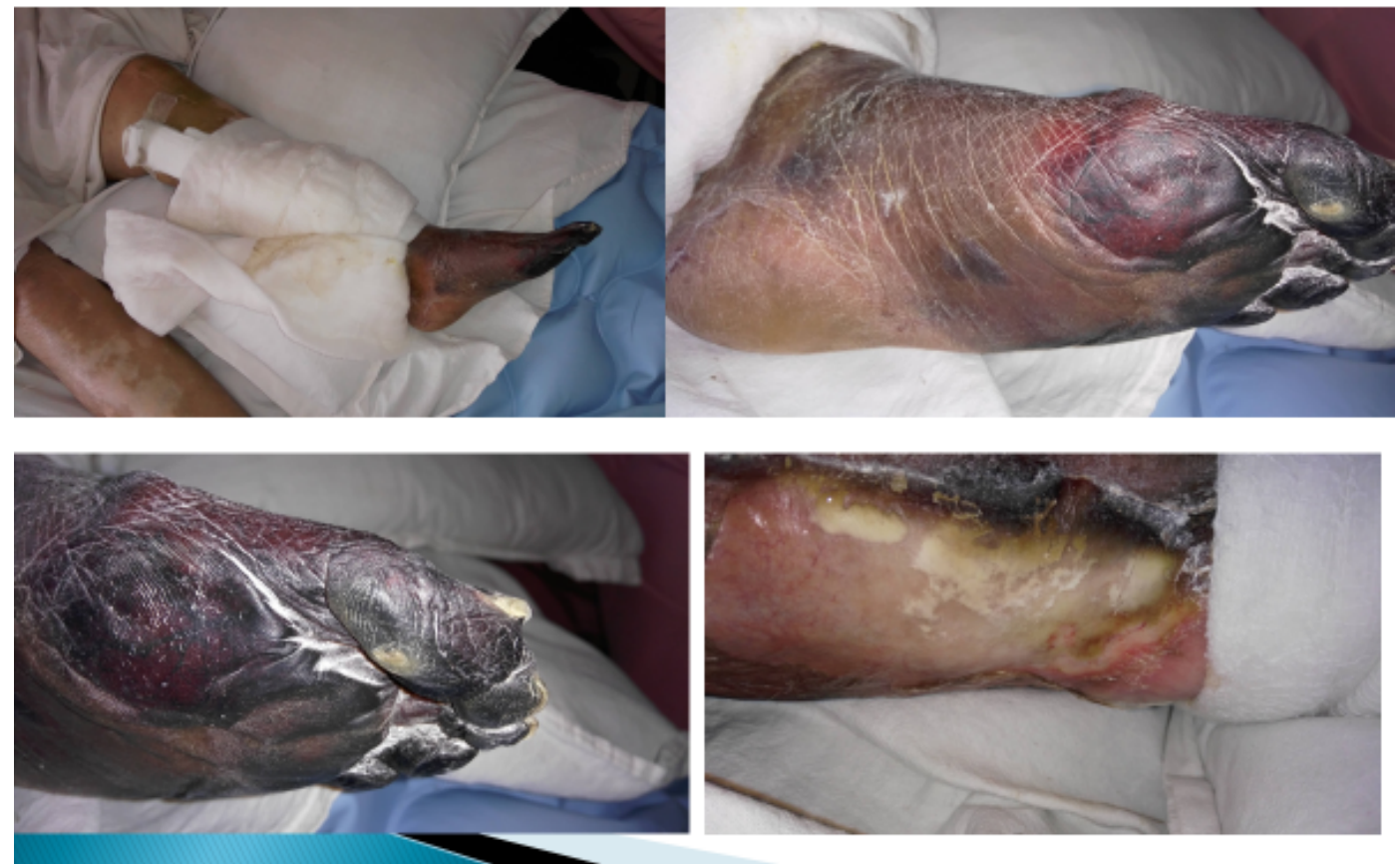

Figure 1. Photographs of affected area (left foot) before cellsonic VIPP treatment

Cellsonic VIPP Treatment: $1^{\text {st }}$ Session on

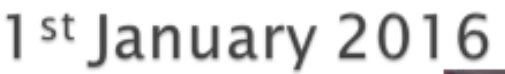

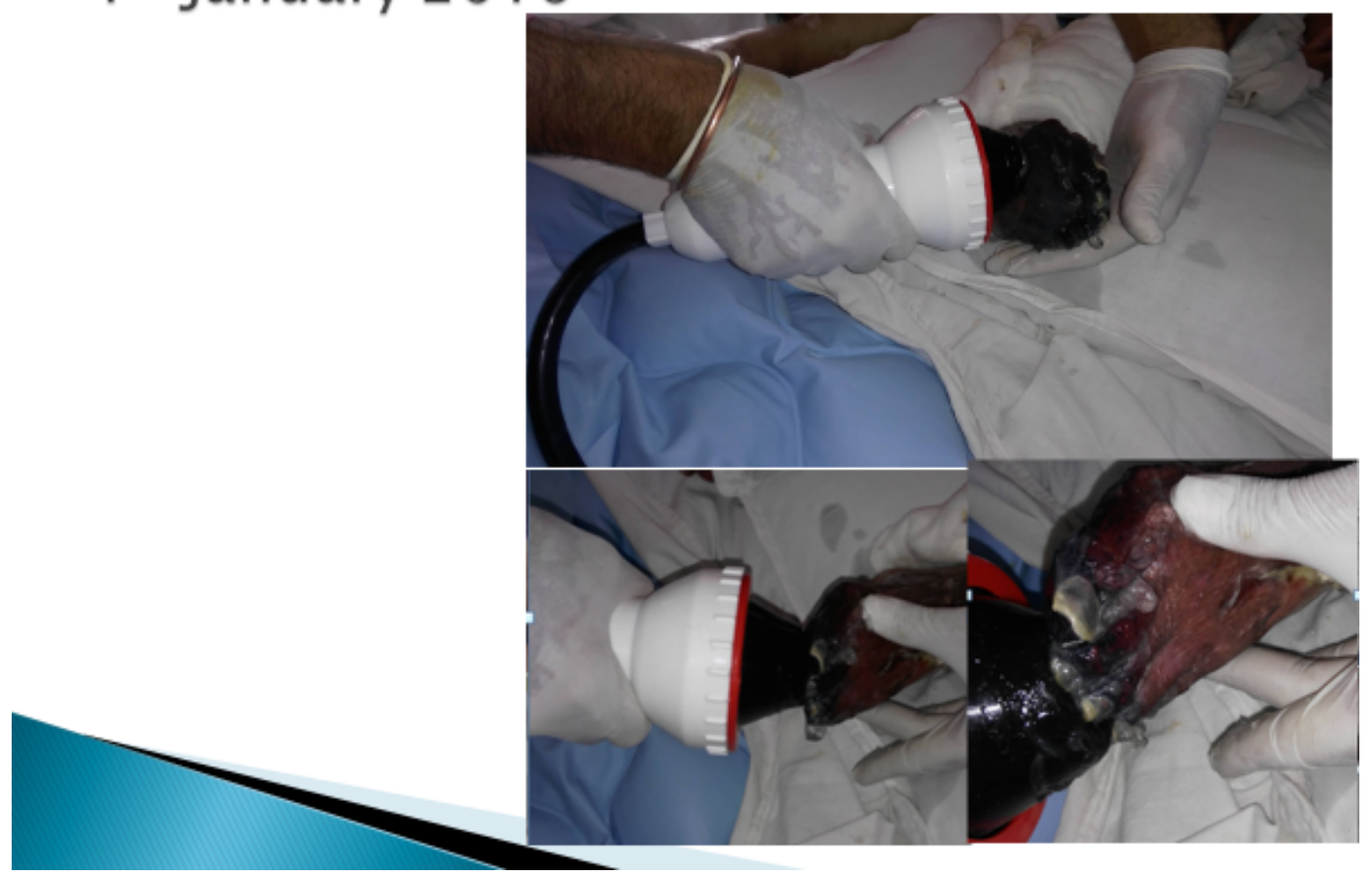

Figure 2. Cellsonic VIPP treatment: $1^{\text {st }}$ session on $1^{\text {st January }} 2016$ 


\section{Photographs of affected area (left foot) after $1^{\text {st }}$ Session of Cellsonic VIPP treatment :}

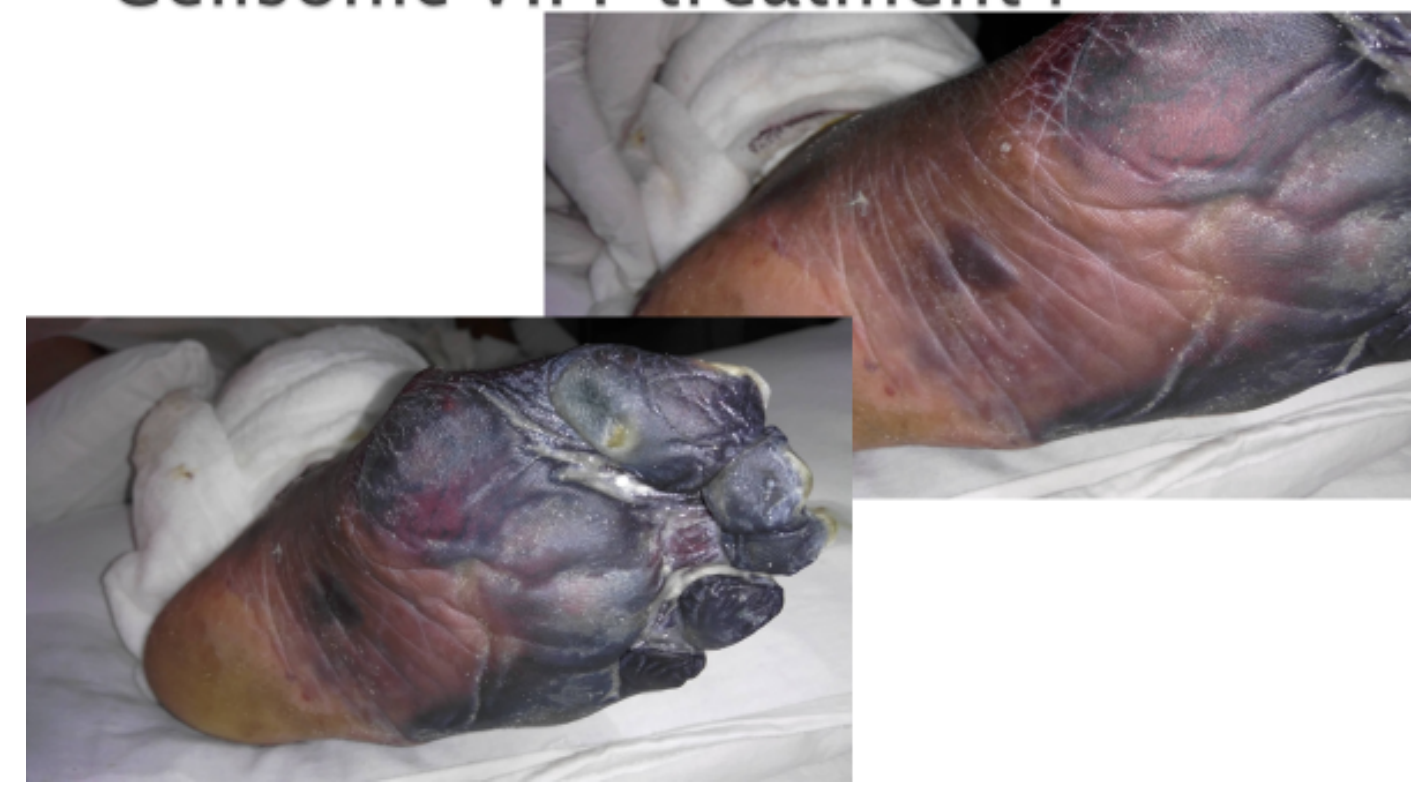

Figure 3. Photographs of affected area (left foot) after $1^{\text {st }}$ session of cellsonic VIPP treatment

\section{Photographs of affected area ( left foot) after $1^{\text {st }}$ Session of Cellsonic VIPP treatment :}

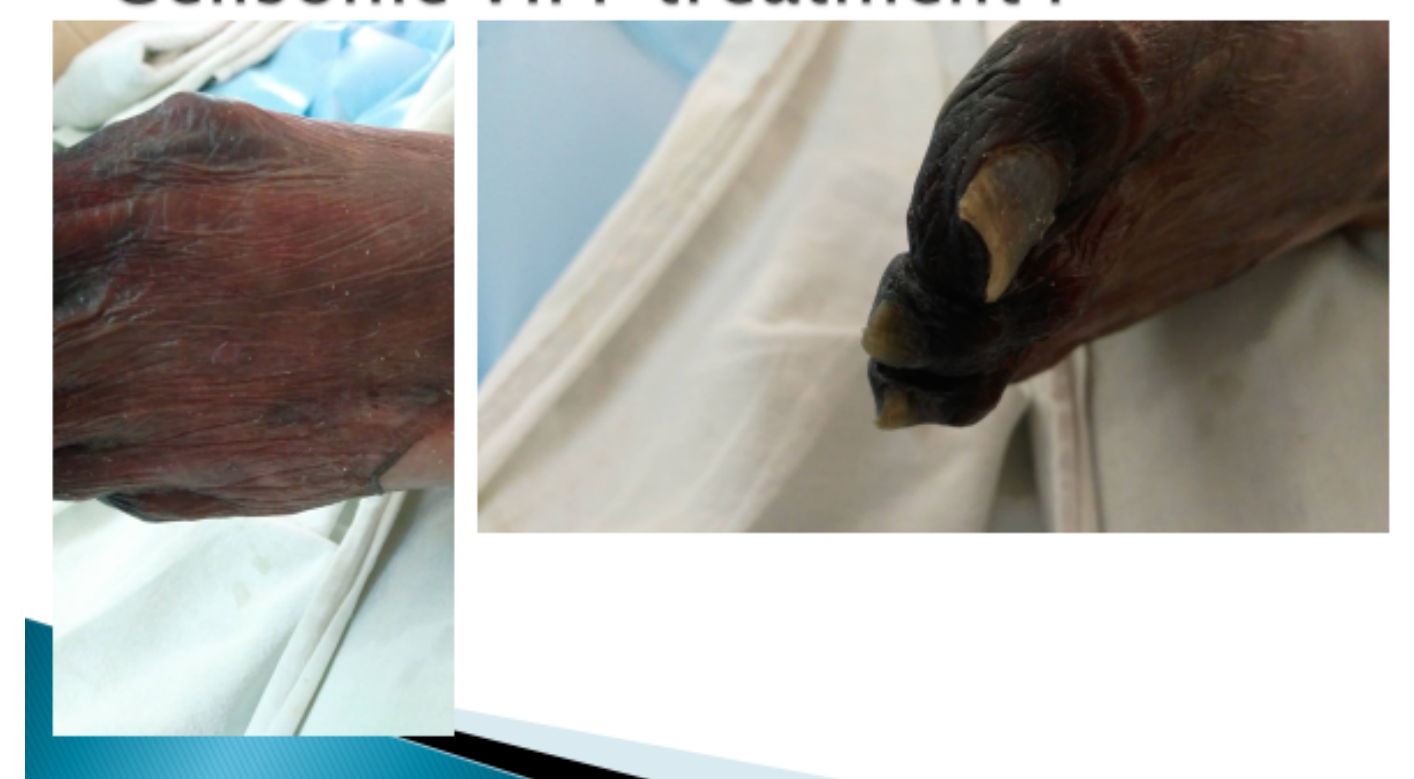

Figure 4. Photographs of affected area (left foot) after $1^{\text {st }}$ session of cellsonic VIPP TREATM 


\section{Photographs of right foot before treatment :}

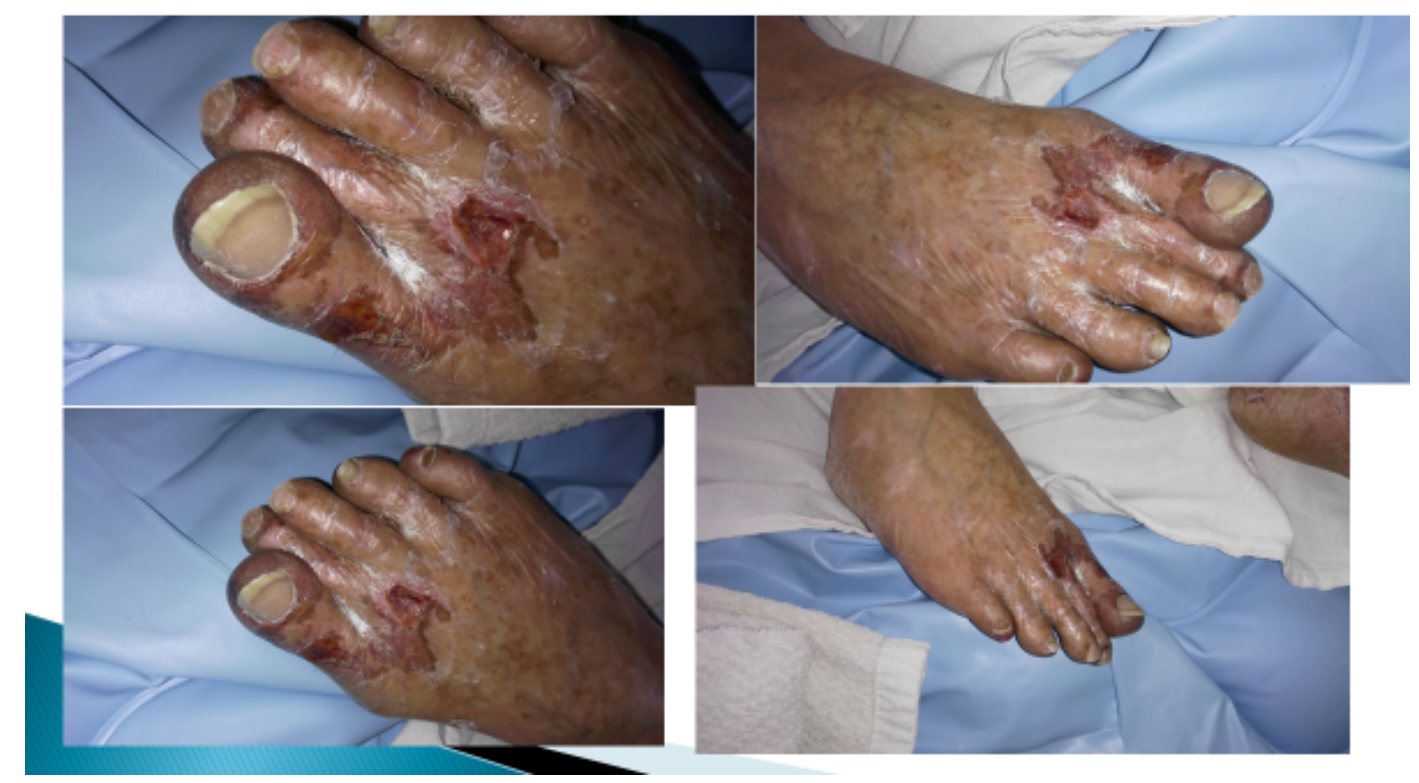

Figure 5. Photographs of right foot before treatment

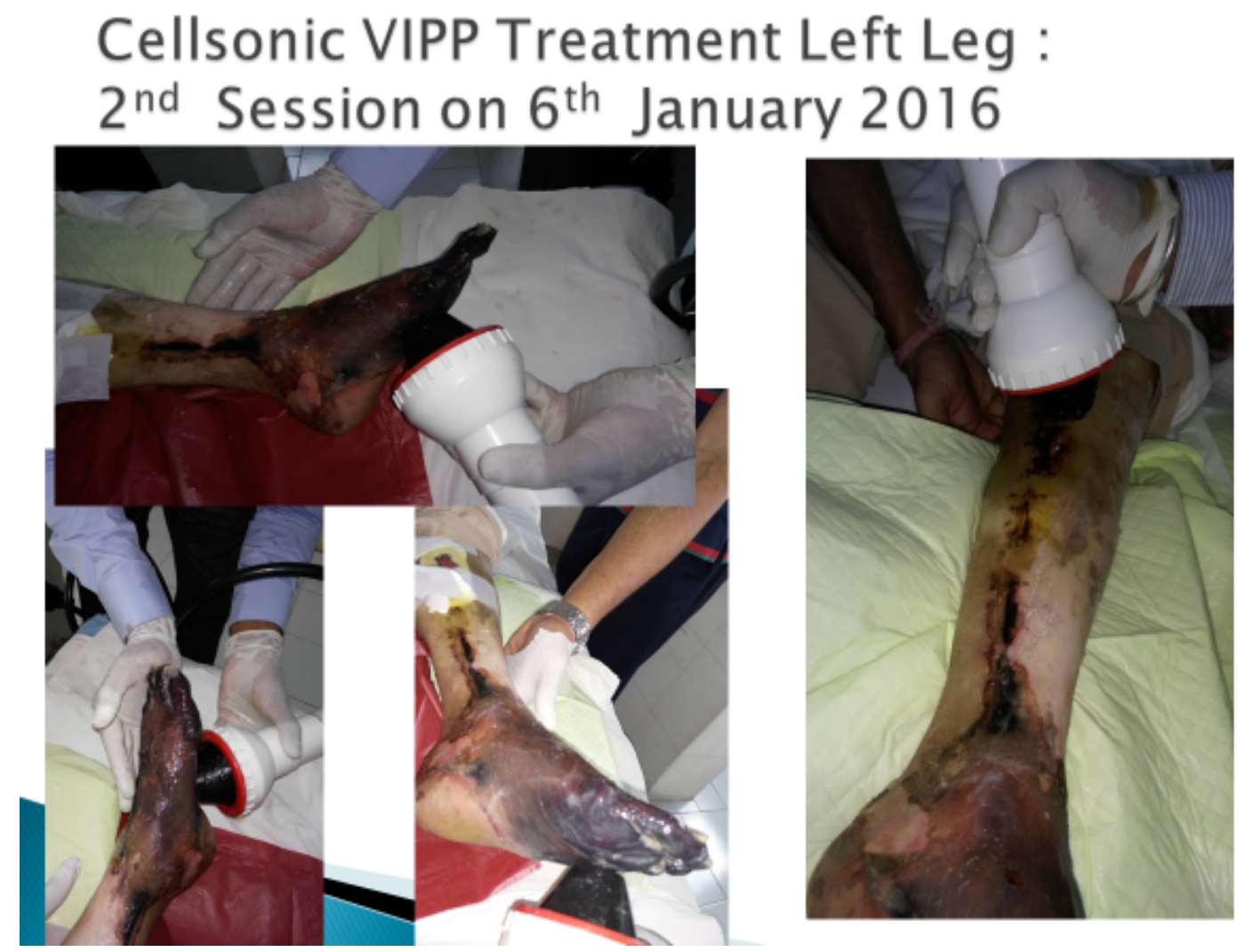

Figure 6. Cellsonic VIPP treatment left leg: $2^{\text {nd }}$ session on $6^{\text {th }}$ January 2016 


\section{Photographs of left foot after $2^{\text {nd }}$ session of treatment :}

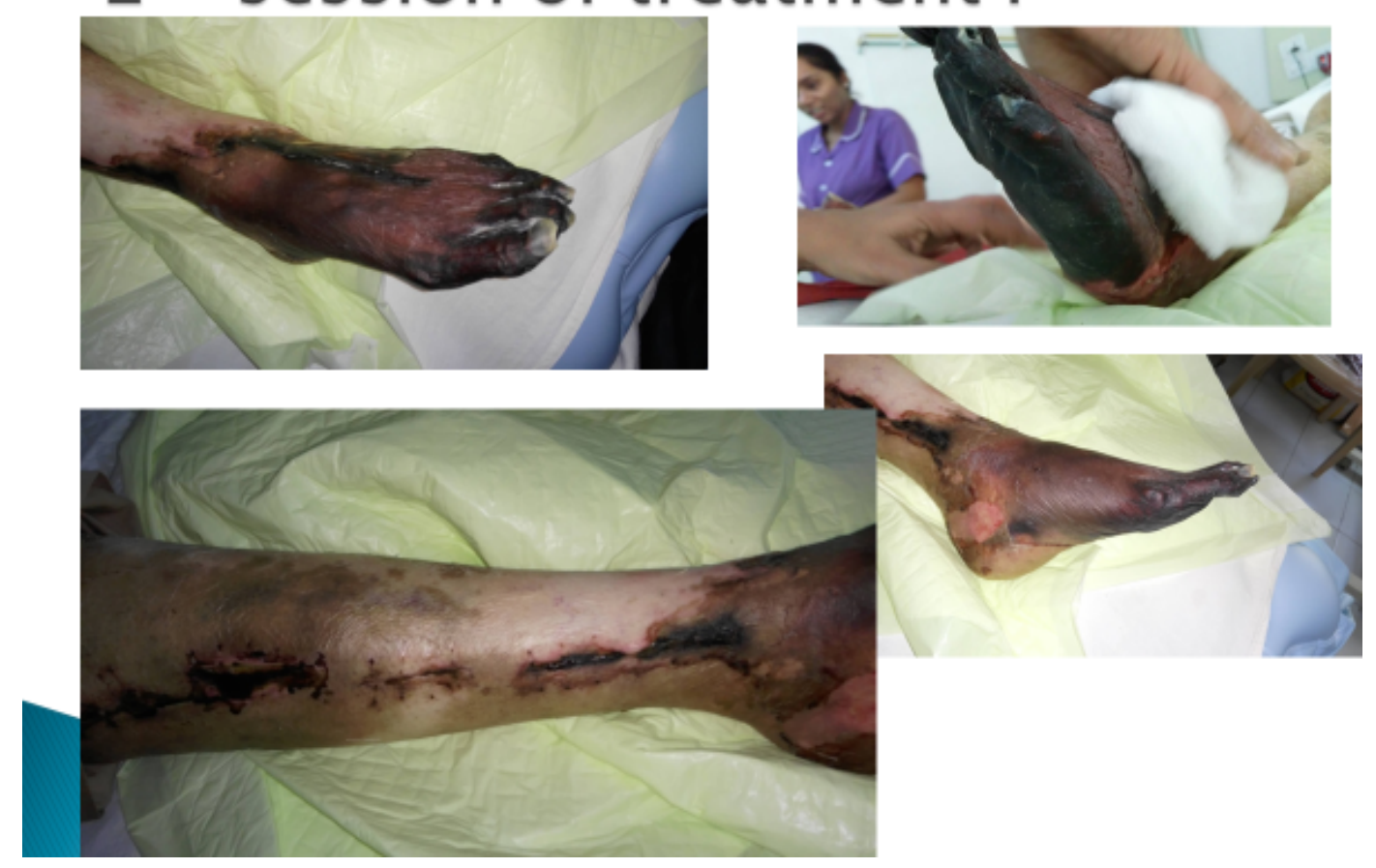

Figure 7. Photographs of left foot after $2^{\text {nd }}$ session of treatment

\section{Photographs of right foot after VIPP treatment Day 2 :}

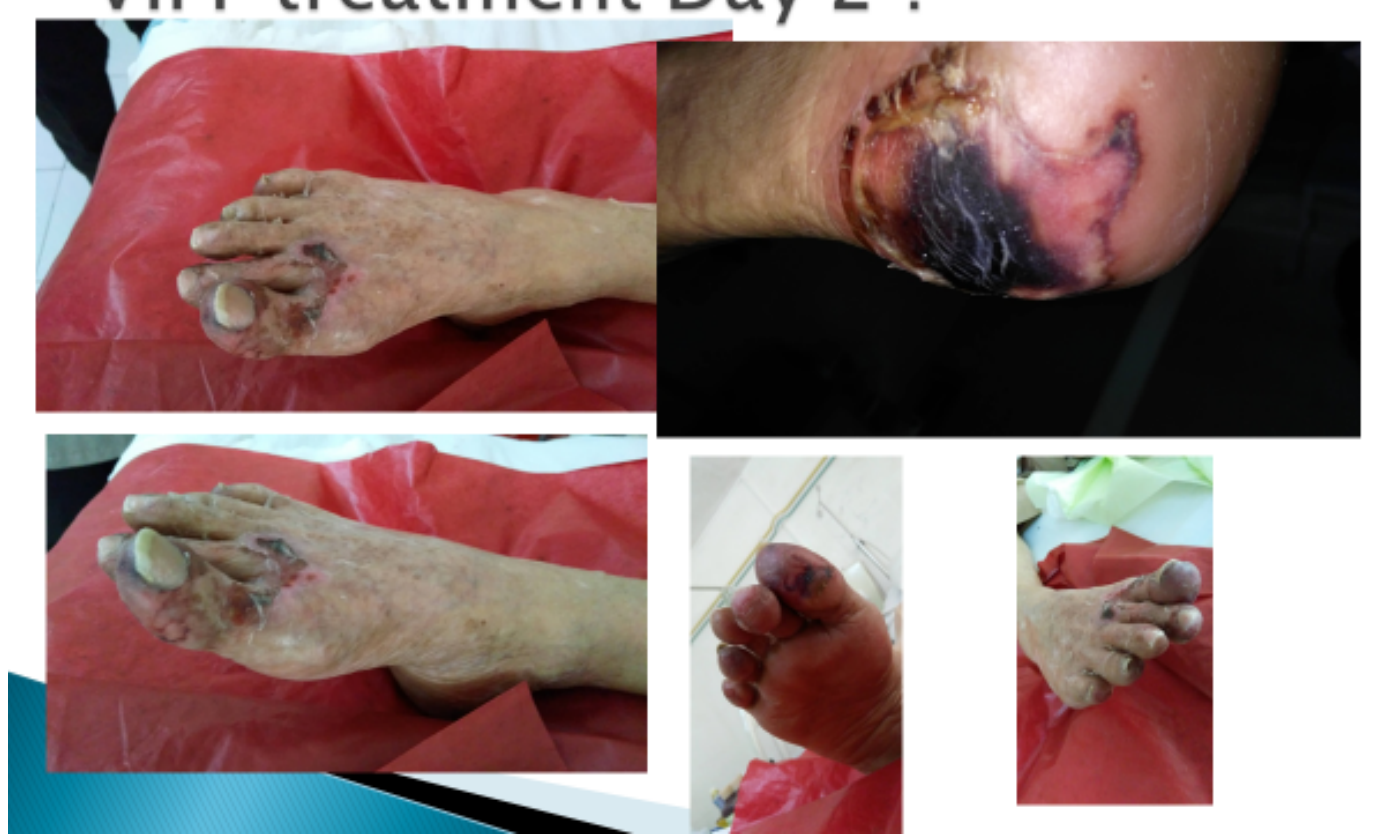

Figure 8. Photographs of right foot after VIPP treatment, Day 2. 


\section{$4^{\text {th }}$ Session $15^{\text {th }}$ January 2016}

- Total shocks given on left foot : 2800

- Total shocks given on right foot : 500

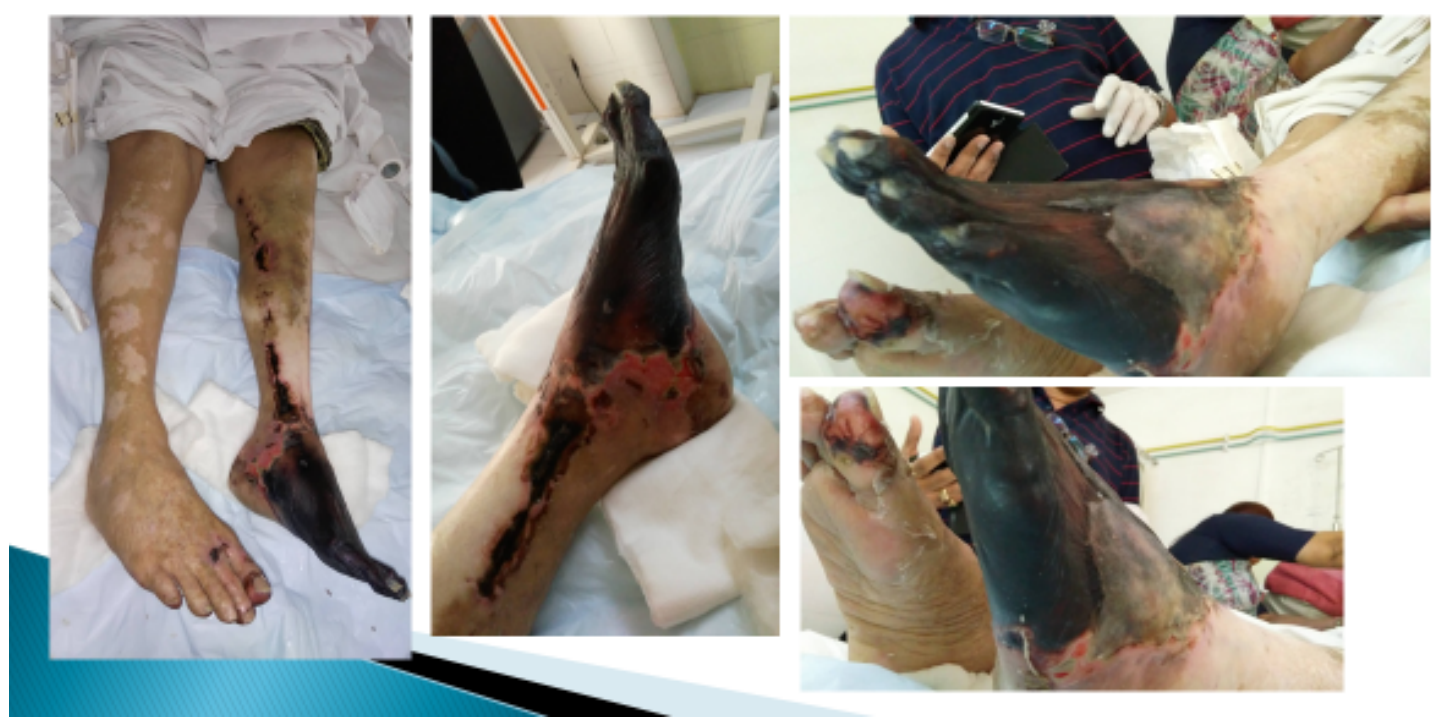

Figure 9. $4^{\text {th }}$ session, $15^{\text {th }}$ January 2016

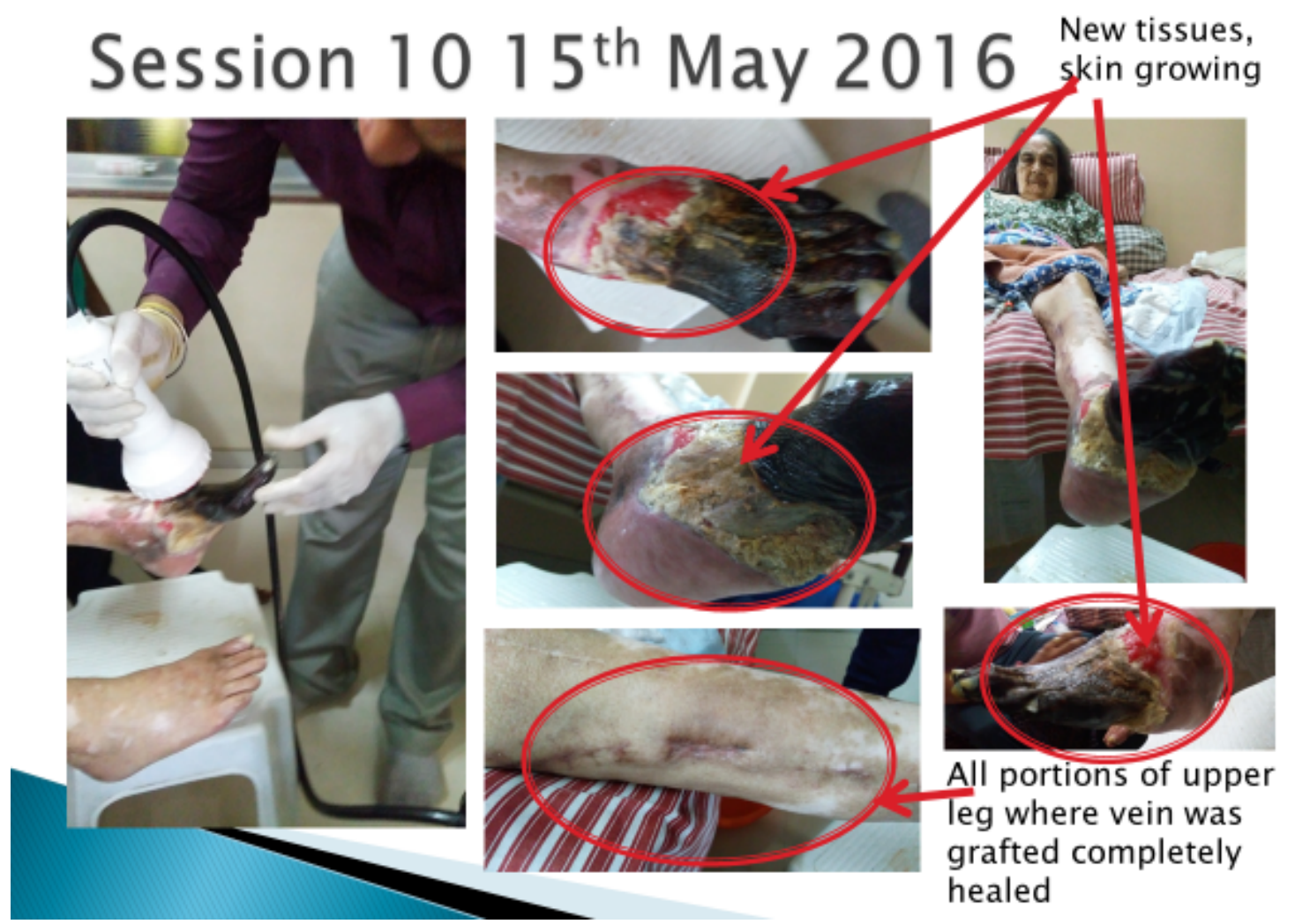

Figure 10. Session 10, 15 $5^{\text {th }}$ May 2016 


\section{Session $11-4^{\text {th }}$ June 2016}

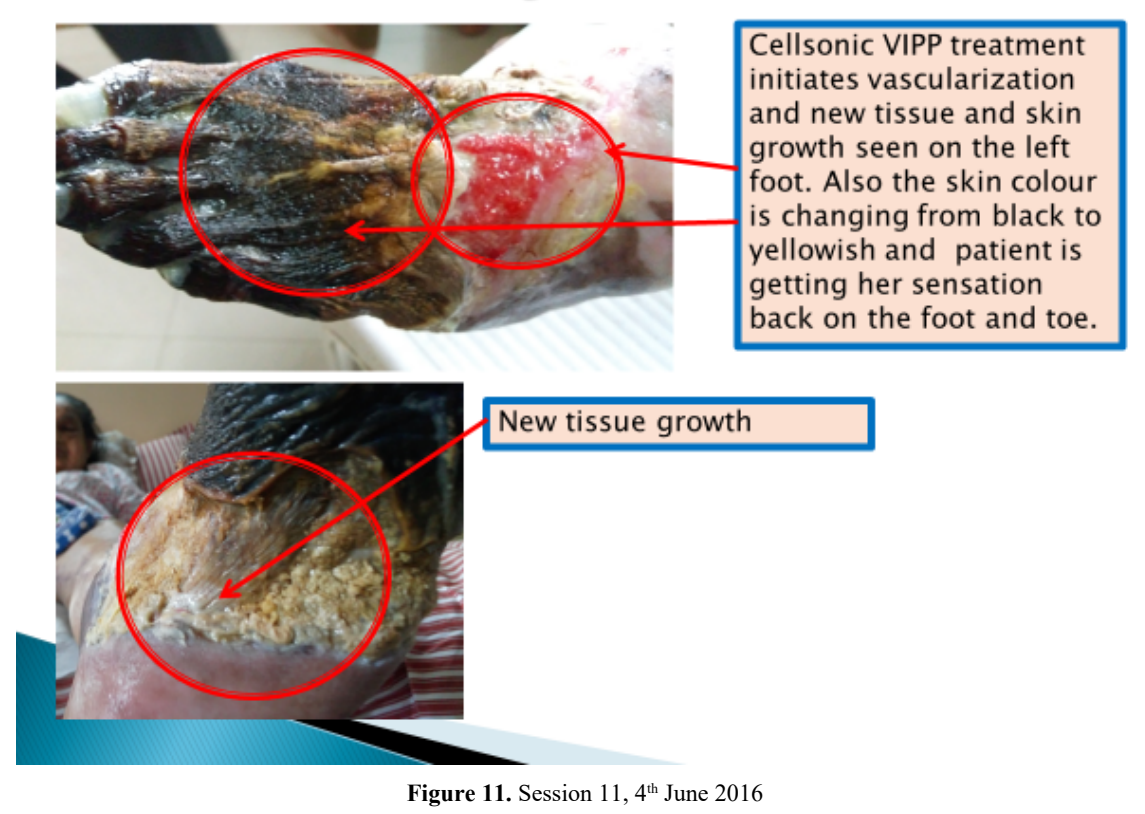

Conventional wound healing has no means of increasing blood flow and killing all infections whatever and wherever they are. Gangrene is the most extreme case because if the infections spread they will poison and kill the patient. Thankfully CellSonic kills the infection. It also stimulates the blood flow and restores the nerves. A chronic wound becomes an acute wound and by repeating the treatments at 2 to 3 -week intervals any infection is stopped.

I complained that the nurse was binding the bandages too tightly and she said she had to obey the doctor. I also encouraged Mrs ... to stand up and to walk across the room if she felt able to with a stick. She wanted to which is a good sign and we must remember she is 81 , diabetic and had a major heart operation in December. The nurse pointed out that the bladder catheter prevented the patient moving. I asked for it to be removed because it had no purpose now that the patient could walk and get to the toilet on her own. Quite apart from the self-dignity this affords, any movement after prolonged immobility is exercise and beneficial. I asked if the patient could sit outside in the sun where she would meet and chat with neighbours, but this was firmly refused. It was as though healing would come from imprisonment. This was not my patient and I had no authority.

For sure the gangrene was stopped with one treatment. Every doctor we met in ... who saw the original photos said she must have an amputation including one doctor who had signed her form for an amputation. When we went to his clinic and showed him the changes after treatment he was impressed.

This is a new branch of medicine that can also bond broken bone. The cases where an amputation is necessary are so remote that to aim for zero amputations is practical. No drugs are used, and it is all non-invasive.

So far, so good. The need for an amputation had long since passed and was now never discussed. The healing of the wound would take time and that was accepted. Then on the $8^{\text {th }}$ November 2016 came the following message:

Mrs.... passed away on 6th Nov in a hospital in .... She was admitted due to a sharp drop in her haemoglobin count. Also, the primary cause of her health failure has been attributed to a urine infection and during her last days her urination had completely stopped.

This is what we were afraid of as she was on catheter continuously since Dec 2015. We have often spoken of the possible dangers of use of catheter and am afraid it seems to be the culprit here.

Anyways what we could manage was not allowing the leg amputation which the expert doctors had deemed so necessary to save her life at that point of time. Not allowing the leg and foot to deteriorate further is still an achievement.

The rule for a doctor is not get emotionally involved with a patient. I break rules. CellSonic would never have achieved what it has done by staying inside the box. The patient had been killed by ignorance, not malice, not neglect, just plain stupidity. The nurse acted as a hired mercenary, which she was. The doctor followed the rule book without thinking. The husband followed the doctor because the doctor is always right. I was thousands of miles away and even if I had gone in shouting it would have done no good.

The lessons for CellSonic were to have full control of a patient and not accept to be a service supplier on behalf of another doctor who does not care to see the whole situation. The lessons for me were personal. To know in the end that I was right is no consolation. I am not answerable to anyone so, probably unlike you reading this account, I can say what I like, and I should have said more when I had the chance. Being polite and correct can be wrong. If you know you are right, SHOUT! Someone's life is at stake.

Copyright: $@ 2017$ Hague A. This is an open-access article distributed under the terms of the Creative Commons Attribution License, which permits unrestricted use, distribution, and reproduction in any medium, provided the original author and source are credited. 